FACTA UNIVERSITATIS

Series: Economics and Organization Vol. 13, N ${ }^{\mathrm{o}} 4$, 2016, pp. 335 - 350

DOI: 10.22190/FUEO1604335C

Original scientific paper

\title{
SOCIAL DIMENSION OF SUSTAINABLE COMPETITIVENESS OF SERBIA AND SELECTED EUROPEAN COUNTRIES
}

\author{
UDC 502.131.1:339.137.2(497.11+4)
}

\author{
Slobodan Cvetanović ${ }^{1}$, Danijela, Z. Despotović ${ }^{2}$, Vladimir Nedić ${ }^{3}$ \\ ${ }^{1}$ University of Niš, Faculty of Economics, Niš, Serbia \\ ${ }^{2}$ University of Kragujevac, Faculty of Economics, Kragujevac, Serbia \\ ${ }^{3}$ The School of Applied Engineering Studies, Kragujevac, Serbia
}

\begin{abstract}
The central idea of sustainable competitiveness is the quest for a model of development that would balance economic prosperity, social sustainability and environmental management. This paper analyzes the social aspect of sustainable competitiveness with the aim of determining the relative position of the Republic of Serbia in relation to selected most competitive and least competitive European countries (according to the value of Social sustainability-adjusted GCI). The basic assumption is that improving sustainable competitiveness of countries must not be done in such a way that economic, social and environmental dimensions of competitiveness are treated as conflicting categories. Based on the data of World Economic Forum, quantitative, qualitative and graphical analysis of the social dimension of sustainable competitiveness of Serbia in relation to the six most competitive and six least competitive countries in Europe (including Serbia) are presented. Using simple correlation and regression analysis, the interdependence of the Global Competitiveness Index and the Social Sustainability Pillar of observed countries is examined.
\end{abstract}

Key words: sustainable development, sustainable competitiveness, social dimension of sustainable competitiveness

\section{INTRODUCTION}

In the current context of globalization, competitiveness constitutes a major economic objective frequently invoked by economic policy-makers worldwide (Pérez-Moreno et al., 2015). In economic theory, there are different views and definitions of competitiveness. A number of researchers insist on the distinction between competitiveness of enterprises and the

Received August 22, 2016 / Accepted October 24, 2016

Corresponding author: Slobodan Cvetanović

University of Niš, Faculty of Economics, Trg Kralja Aleksandra 11, 18000 Niš, Serbia

E-mail: slobodan.cvetanovic@eknfak.ni.ac.rs 
competitiveness of countries. Basically, what distinguishes the country's competitiveness from the competitiveness of enterprises is the process of creating economic value in society. The economic value is created only by enterprises whereas the country can establish an environment that supports or hinders the activities of enterprises (Stoneman, 1995). In this context, some economists reject the very logic of the use of the term competitiveness of the country (Krugman, 1994). However, most economists agree in their assessment that the 21 st century will be a period of global economic competition, thanks mainly to the growing importance of knowledge, education and innovation in the development of economy and society (Dragicevic, 2012). In addition, clean technologies and ecoinnovations are key factors to maintain and/or improve economic competitiveness and secure environmental sustainability of different sectors and the economy as a whole (Coenen \& Díaz López, 2010).

In modern business conditions, special attention is paid to international competitiveness, regardless of whether the individual products, companies, industries or the national economies are considered. International competitiveness is a condition in which a country can, under free and fair market conditions, produce goods and services that meet the demands of the world market, while maintaining or increasing the real income of its citizens (Hatzichronoglou, 1996).

The study subject of competition oriented economic reality is the focus on successful enterprises, industries, countries or group of countries. In contrast, any theoretical understanding of this phenomenon is inevitably linked to reductions and simplifications. Only a small number of differences among the participants, leading to differences in the studied countries, industries or companies, can be taken into account, while the far greater number of them must be disregarded. The most frequently used differences in explaining the causes of competitiveness lie in the various offers of factors of production such as labor and capital, unevenly available technologies, different possibilities for utilization of economies of scale, etc.

Conceptual term sustainable competitiveness involves treatment of the phenomenon of competitiveness in the light of the demand of the paradigm of sustainability, which is a research approach that links the requirements of economic development, environmental protection and the improvement of social life (Filipovic \& Despotovic, 2014; Cvetanovic et al., 2014). So, in order for sustainability to be achieved, it is important that these three components are given equal attention. However, until the end of the previous century, debates about sustainable competitiveness were dominated by environmental and economic dimensions. Although the social sustainability was treated as one of three basic dimensions of development, it has not been recognized as an individual field of theoretical analysis, empirical verification and practical application until the last ten years (Mirkov, 2012).

Contribution to the operational use of the concept of sustainability, especially with regard to the simultaneous treatment of its economic, social and environmental dimensions is an approach to measure the competitiveness of countries by World Economic Forum that started in 2011.

The subject of this paper is the analysis of the social aspect of sustainable competitiveness. Giving attention to the phenomenon of the social dimension of competitiveness, it should be noted that this is a new area of research (Stiglitz et al., 2009; Despotovic et al., 2015), and that there is not a large number of empirical analyses of this phenomenon in the literature. The problem that is being investigated in this paper may be reduced to the question: what is the 
relative position of the Republic of Serbia according to the criteria of the social dimension of sustainable competitiveness in relation to the most competitive and least competitive European countries according to data of the World Economic Forum? With the aim of achieving an acceptable answer to this question, we compared indicators of the social dimension of sustainable competitiveness of Serbia with corresponding indicators of six European countries that have the highest rank (Denmark, Netherlands, Finland, Germany, Norway and Switzerland) and five countries that have fallen to last positions (Croatia, Romania, Greece, Moldova and Macedonia) according to the criterion of Social sustainability- adjusted GCI in Europe in 2014. The relationship between the Global Competitiveness Index (GCI) and the Social sustainability pillar of selected countries in 2014, was analyzed using simple linear correlation analysis.

\section{SUSTAINABLE COMPETITIVENESS: THE METHODOLOGY OF THE WORLD ECONOMIC FORUM}

The Global Competitiveness Report 2011-2012 (Schwab \& Sala-i Martin, 2011), in addition to GCI also presents a Sustainability-Adjusted Global Competitiveness Index SGCI. This index is introduced in its preliminary version with emphasis on the analysis of social and environmental elements that maintain high levels of long-term economic competitiveness. The index includes mainly all the elements presented in the GCI, which are important for understanding the competitiveness of countries in the short and long term (governance, education and health, infrastructure, the functioning of markets and innovation), but also a number of additional indicators (demography, social cohesion, environmental management). In this way, GCI is a short-term and medium-term view of the future, while the Sustainability-adjusted GCI presents a long-term view (for 20 years) on the phenomenon of competitiveness of countries. Such an approach makes it possible to highlight the link between competitiveness and sustainability (Fig. 1).

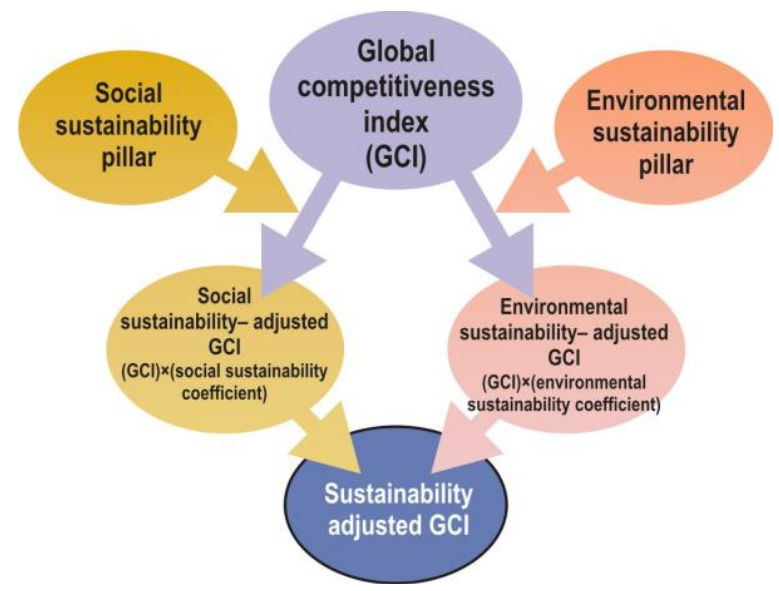

Fig. 1 The analytical framework of the sustainability-adjusted GCI (Modified according to Blanke, 2013, p. 52) 
The ultimate sustainability (according to the analytical framework) is the result of two indices of sustainability: Social sustainability-adjusted GCI and Environmental sustainabilityadjusted GCI. For the pillar of social sustainability the three following conceptual elements are defined: access to essential needs, economic exclusion and social cohesion. For the pillar of environmental sustainability the following three conceptual elements are defined: environmental policy, the use of renewable resources and the degradation of the environment.

Presentation of the analytical framework in Fig. 1 indicates that competitiveness alone does not necessarily lead to a sustainable level of prosperity. The realization of economic progress is essential for improving living standards. However, within this process the ability of countries to generate prosperity for its citizens in a sustainable manner is assessed. In other words, competitiveness is a necessary, but not a sufficient condition for social prosperity. Hence, there is a need for measures of competitiveness that are tailored to the requirements of social and environmental sustainability.

The methodology for measuring sustainable competitiveness index is based on the premise of a linear impact of socially sustainable and environmentally sustainable dimension of competitiveness. The result is a Sustainability-adjusted GCI as the average of Social sustainability-adjusted GCI and Environmental sustainability-adjusted GCI. Social and environmental dimensions of sustainability are treated as independent adjustments for the performance of each country in the global competitiveness index.

Since there is no clear theoretical guidance for assigning weights to individual elements, indicators were given equal weight within each pillar. Each pillar was transformed into an "adjustment coefficient" with a range of 0.8 to 1.2 , which is then used to match the results of the global competitiveness index up or down within this range. This is manifested in a harmonized result that is maximum $20 \%$ lower or $20 \%$ higher than the basic value of the global competitiveness index.

Due to the fact that some of the aspects of sustainability are assessed within the pillars of social and environmental sustainability, the results reflect the overall performance of all aspects instead of a particular element. In a sense, this means that the poor performance in some aspects can be compensated by good results in other areas.

Instead of the 144 economies covered by GCI, in the analysis of sustainable competitiveness of the World Economic Forum for 2012 a sub-sample of 79 countries was presented, and in 2013 it was expanded to 121 countries. The availability of data is a major challenge and limitation in this procedure, because for many of the used concepts, there are no measures or data are available only for a limited number of countries.

\section{SubJeCt, RESEARCH METHOdOLOGY AND HyPOTHESES}

This research is focused on the position of indicators of social sustainability of Serbia in relation to the six most competitive and six least competitive countries in Europe in 2014, as well as their impact on the competitiveness of the surveyed countries.

The survey was conducted in the following four steps:

- search and analysis of the reference framework is carried out and the data collected,

- the data is then filtered, aggregated, and structured according to the needs of further analysis,

- the position of Serbia and the observed group of countries is shown tabularly and graphically according to: 
- three groups of parameters of social sustainability,

- global ranking of index of sustainable competitiveness (SGCI) as well as its social component,

- SGCI values and its social component

- at the end statistical methods of linear correlations analysis of the based competitiveness (GCI) and social components SGCI (Social sustainability pillar) are applied for all of surveyed countries.

On the basis of analytical framework of sustainable competitiveness, the following hypothesis are stated:

- H1: There is a significant difference in the achieved level of Indicators of social sustainability between the six most competitive countries and the six least competitive countries in Europe (including Serbia),

- H2: There is no significant difference in the achieved level of Indicators of social sustainability between Serbia and the six least competitive countries in Europe,

The hypothesis $\mathrm{H} 1$ is logical as the group of the most competitive countries comprise democratically organized societies with the oldest tradition of freedom and harmony. However, at first glance, this axiom is not necessarily true for all observed indicators (Fig. 2), so that, this claim requires a more detailed analysis of the available data.

The hypothesis $\mathrm{H} 2$ seems also logical because Serbia geographically, economically but also in terms of the achieved level of democratic values of modern civil communities can join the group of the least competitive countries in Europe. However, as with previous hypothesis, the accuracy of this statement for all observed indicators of the social component of sustainable competitiveness index cannot be accepted without detailed analysis.

\section{A COMPARATIVE ANALYSIS INDICATORS OF SOCIAL SUSTAINABILITY}

This research is focused on the position of indicators of social sustainability of Serbia in relation to the six most competitive and six least competitive countries in Europe in 2014, as well as their impact on the competitiveness of the surveyed countries.

Using data on sustainable competitiveness in the Global Competitiveness Report 2014-15 (Bilbao-Osorio et al., 2012), in this part of the paper a comparative survey of indicators of the social sustainability of the Republic of Serbia and selected most competitive (Switzerland, Norway, Netherlands, Germany, Denmark, Finland) and least competitive countries in Europe (Greece, Macedonia, Moldova, Romania, Croatia) is presented.

For social sustainability, the Forum identifies three conceptual elements (Fig. 2).

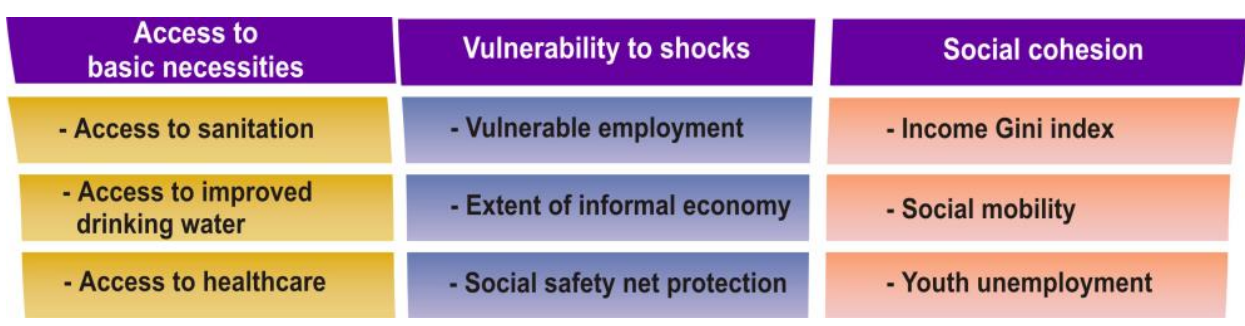

Fig. 2 Indicators of social sustainability (source: Blanke (2013)) 
The first category depicts the population access to the basic necessities of life (Table 1). It includes three indicators: access to sanitation facilities, access to drinking water of improved quality and access to health care services. This category is a measure of inclusion, as well as a measure to satisfy basic physical needs. The population that has poor access to water, food, shelter, health care and sanitation facilities cannot fully develop their creative potential.

Graphical Visualization of analyzed variables is given in Figures 3-5, where the observed characteristics by selected groups of countries are defined as the average of the results that countries in the studied groups achieved in the particular domain of social sustainability.

Table 1 Access to basic necessities (source: Bilbao-Osorio et al. (2012))

\begin{tabular}{llccc}
\hline Country & $\begin{array}{c}\text { Access to sanitation } \\
\text { facilities } \\
\%\end{array}$ & $\begin{array}{c}\text { Access to drinking water } \\
\text { of improved quality }{ }^{2}\end{array}$ & $\begin{array}{c}\text { Access to health care } \\
\text { services } \\
\text { Score }(1-7)\end{array}$ \\
\hline 1 & Denmark & 100.00 & 100.00 & 6.39 \\
2 & Finland & 100.00 & 100.00 & 6.42 \\
3 & Germany & 100.00 & 100.00 & 6.32 \\
4 & Netherlands & 100.00 & 100.00 & 6.59 \\
5 & Norway & 100.00 & 100.00 & 6.73 \\
6 & Switzerland & 100.00 & 100.00 & 6.81 \\
\hline & Average & 100.00 & 100.00 & 6.54 \\
\hline 1 & Croatia & 98.00 & 99.00 & 5.25 \\
2 & Greece & 99.00 & 100.00 & 4.69 \\
3 & Macedonia, FYR & 91.00 & 99.00 & 5.01 \\
4 & Moldova & 87.00 & 97.00 & 4.29 \\
5 & Romania & 72.00 & 88.00 & 3.95 \\
6 & Serbia & 97.00 & 99.00 & 3.99 \\
\hline & Average & 90.67 & 97.00 & 4.53 \\
\hline
\end{tabular}

${ }^{1}$ Percentage of total population using improved sanitation facilities ${ }^{2}$ Percentage of the population with access to improved drinking water quality ${ }^{3}$ How accessible is healthcare in your country?

[ 1 = limited - only the privileged have access; 7 = universal - all citizens have access to healthcare $]$

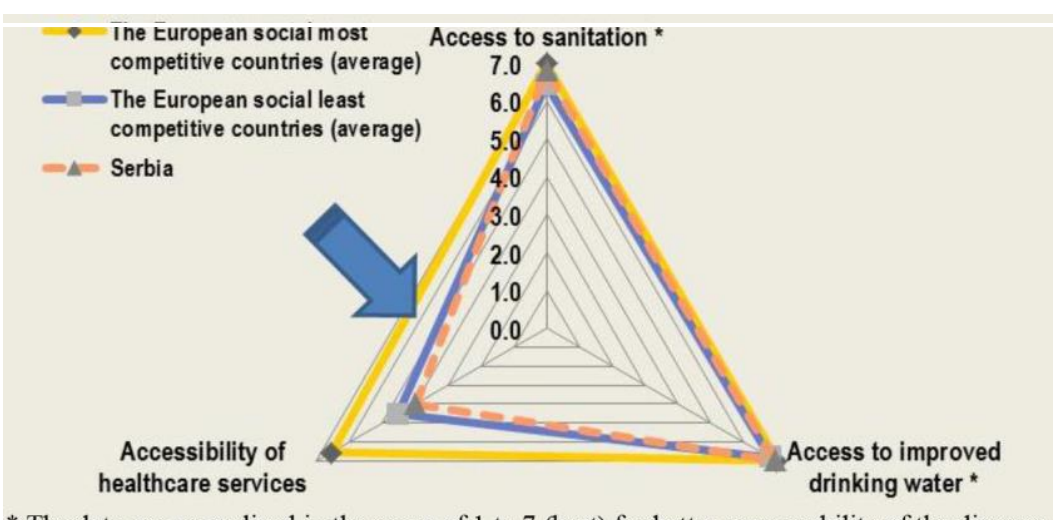

* The data are normalized in the range of 1 to 7 (best) for better comparability of the diagram

Fig. 3 Comparison by elements of access to basic necessities 
Comparative survey in Fig. 3 indicates the parameters about access to basic necessities within the expected relations. The least competitive countries as a group, slightly lagging behind in all observed performances in the field of access to basic necessities, with the biggest problem identified in access to health care (sustainable competitive countries in Europe have a better result of this parameter for nearly $40 \%$ ). Furthermore, it is evident that Serbia regarding the first two parameters is slightly ahead in relation to the average value within the group of least sustainable competitive European countries, while the parameter of access to health care is much worse than the average for this group. This indicates that in respect to the first two parameters, all European countries reached almost maximum availability, while for the much more sophisticated parameter of access to health care, there are still considerable differences among European countries.

The second category is associated with the concept of perceived economic security (Table 2). It evaluates the vulnerability of the population to economic exclusion. There are three indicators by means of which the vulnerability of the population is evaluated: vulnerable employment as a percentage of total employment, the extent of informal economy and security in the form of social safety net. Vulnerable employment indicator measures the percentage of people who are self-employed in small enterprises or in small family firms, which cannot provide the level of income sufficient to meet the standards of living, and may prove to be an unstable measure, especially in times of economic hardship. The extent of the informal economy provides a picture of how well the workforce is integrated into the official structures. The workforce that is less integrated makes workers to be more vulnerable to concerns about job loss, aging, maternity, disability or illness. Third, security in the form of social safety net is

Table 2 Economic exclusion

(source: Bilbao-Osorio et al. (2012))

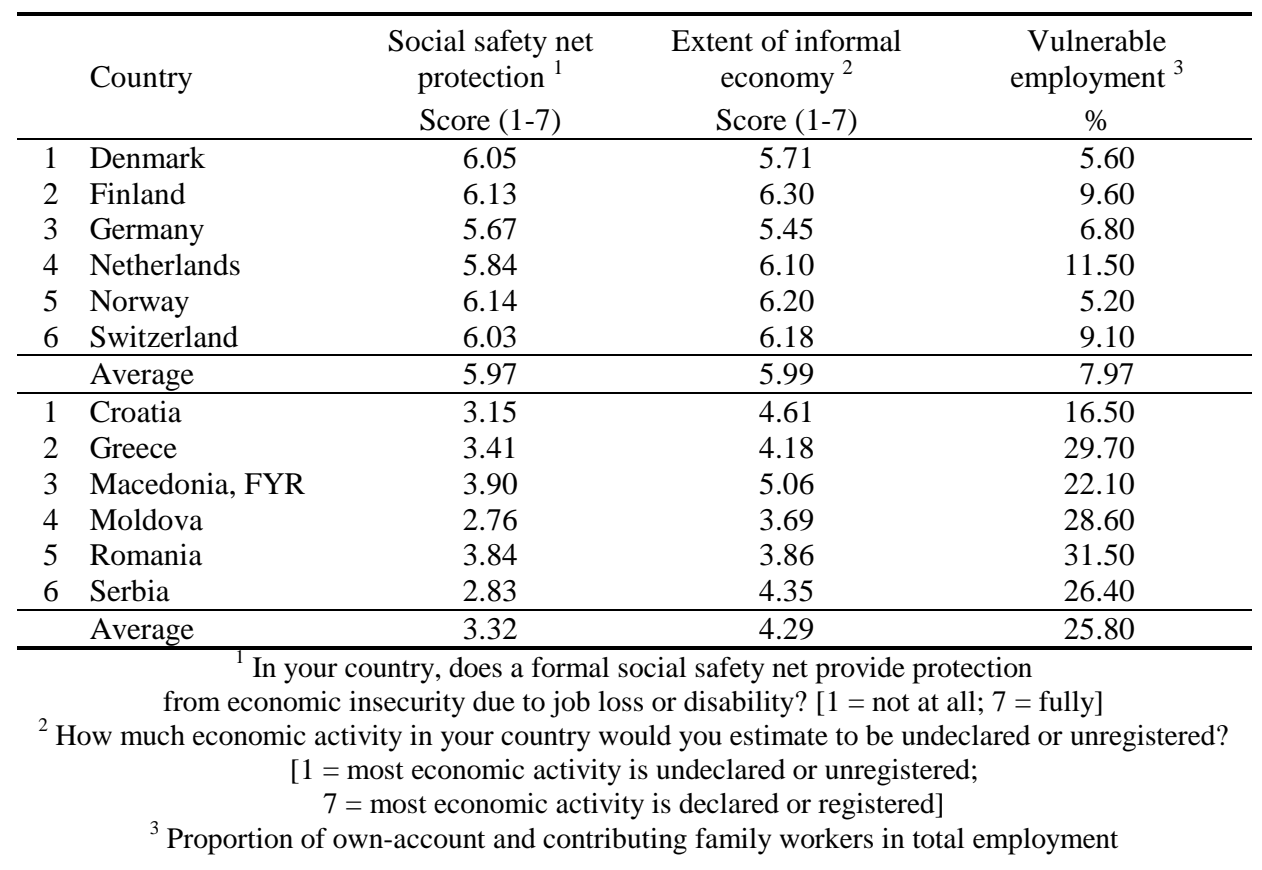


an additional measure of protection in times of financial and economic instability; it allows households to maintain their quality of life and overcome the crisis without falling into the poverty traps. Safety protection also leads to a sense of financial security that allows individuals to undertake investment and entrepreneurial risk, acting on stimulating economic activity.

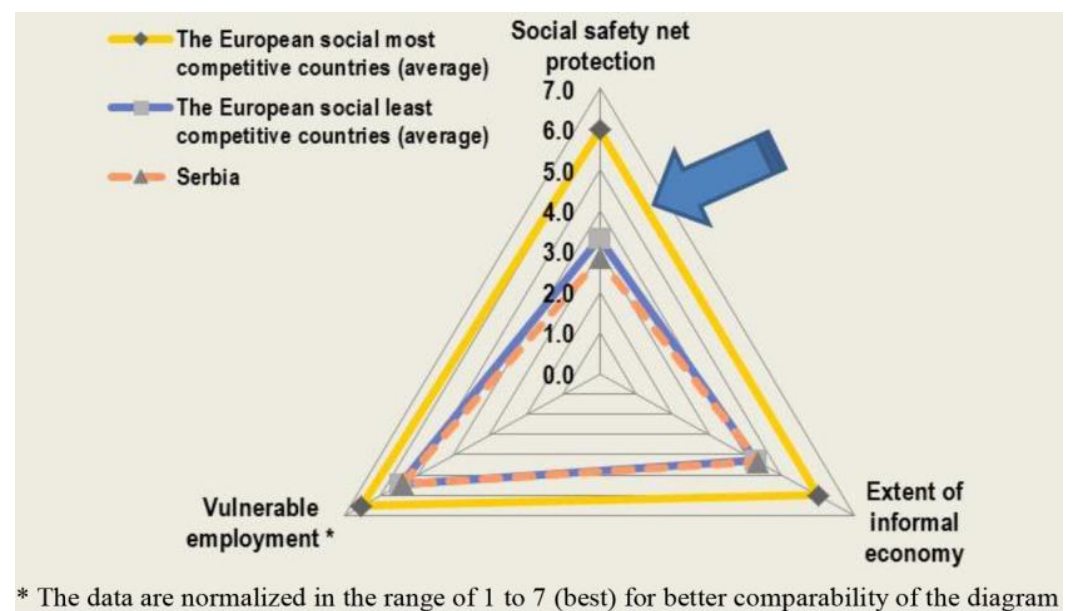

Fig. 4 Comparison in the area of economic exclusion

Considering parameters describing vulnerability to economic exclusion, the group of the most sustainably competitive countries in Europe has significantly and expected better score than the group of least sustainable competitive European countries (Fig. 4). The difference in values of social safety net protection, and extent of informal economy is about $40 \%$ in favor of sustainably most competitive countries in Europe. In the third parameter of vulnerable employment, the difference in favor of sustainably most competitive European countries is more disconcerting and on average reaches a ratio of 1 to 3.5 (individually exceed the ratio of 1 to 6 ). It is noticeable that Croatia, considering the parameter vulnerable employment, moved closer to more successful half of the European countries, in contrast to Moldova, which is for all three parameters almost at the end of the group of least sustainably competitive European countries.

The third and last category estimates social cohesion (Table 3 and Fig. 5). The assessment includes three indicators: the Gini coefficient, social mobility and youth unemployment. The Gini coefficient is included in the index of social cohesion due to the fact that relative poverty may prevent families with low incomes to have access to the same opportunities as families with high incomes. For indicator of social mobility in the context of sustainable competitiveness, it is crucial that the next generations can improve their condition regardless of the socioeconomic status of their parents. From a purely economic perspective, the absence of such social mobility can be harmful to human capital development, as qualified individuals in a society that does not support them in progress, could decide to emigrate; if they stay, the economy in which they live will not improve their skills. In addition, the low expectations of the future regarding expressive unemployment and inequality, can also converge to encouraging political instability. Thirdly, in the wider conceptual level, social mobility is a direct measure of the freedom of manifesting human development. Finally, high youth unemployment can reduce social cohesion and cause significant economic and social costs, depreciating overall earnings 
during the working life of unemployed workers, acting negatively on their health and putting at risk the health and educational success of children of unemployed parents. From an economic point of view, high youth unemployment reflects the failure of society to mobilize existing resources and build productive potential, which in turn acts on the reduction of demand, eroding business confidence and the prospects for investment and job creation.

Table 3 Social cohesion

(source: Bilbao-Osorio et al. (2012))

\begin{tabular}{|c|c|c|c|c|}
\hline \multicolumn{2}{|r|}{ Country } & $\begin{array}{c}\text { Gini index } \\
\%\end{array}$ & $\begin{array}{c}\text { Social mobility }^{2} \\
\text { Score (1-7) }\end{array}$ & $\begin{array}{c}\text { Youth unemployment } \\
\%\end{array}$ \\
\hline 1 & Denmark & 28.10 & 6.06 & 14.14 \\
\hline 2 & Finland & 25.90 & 6.39 & 18.96 \\
\hline 3 & Germany & 28.30 & 5.54 & 8.13 \\
\hline 4 & Netherlands & 25.40 & 5.90 & 9.48 \\
\hline 5 & Norway & 22.60 & 6.26 & 8.46 \\
\hline \multirow[t]{2}{*}{6} & Switzerland & 28.70 & 6.35 & 8.44 \\
\hline & Average & 26.50 & 6.08 & 11.27 \\
\hline 1 & Croatia & 30.50 & 3.67 & 43.05 \\
\hline 2 & Greece & 34.30 & 3.89 & 55.26 \\
\hline 3 & Macedonia, FYR & 43.56 & 4.14 & 53.91 \\
\hline 4 & Moldova & 33.03 & 3.39 & 13.09 \\
\hline 5 & Romania & 33.20 & 3.43 & 22.68 \\
\hline \multirow[t]{2}{*}{6} & Serbia & 29.62 & 3.04 & 51.05 \\
\hline & Average & 34.04 & 3.59 & 39.84 \\
\hline & $\begin{array}{r}{ }^{1} \text { Measure } \\
{ }^{2} \text { To } \\
\text { to improve } \\
\text { the socioecono } \\
\text { economic situati }\end{array}$ & $\begin{array}{l}\text { me inequality [ } \\
\text { tent do individu } \\
\text { conomic situati } \\
\text { tus of their pare } \\
\text { significant opp }\end{array}$ & $\begin{array}{l}\text { fect equality; } 100=1 \\
\text { your country have th } \\
\text { ugh their personal ef } \\
=\text { little opportunity } \\
\text { y exists to improve o }\end{array}$ & $\begin{array}{l}\text { ct inequality] } \\
\text { ortunity } \\
\text { regardless of } \\
\text { s to improve one's } \\
\text { economic situation] }\end{array}$ \\
\hline
\end{tabular}

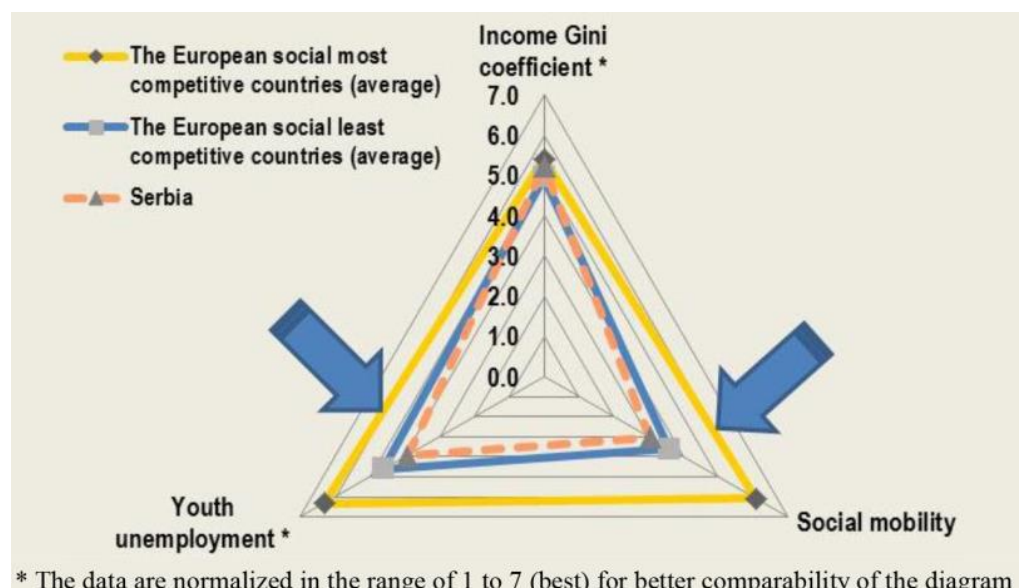

Fig. 5 Comparison in the field of social cohesion 
Social cohesion (Fig. 5) is the third group of parameters by which the social dimension of competitiveness of countries is examined. Available data illustrate the existence of a significant gap between the selected group of sustainable competitive and sustainable uncompetitive European countries. The most expressive difference is observed in the parameter of youth unemployment and in some countries it exceeds the ratio of 1:5 in favor of sustainable competitive countries. Particularly worrying is the fact that considering this parameter, in addition to generally poor results in group of sustainable uncompetitive European countries, Serbia has by far the worst position compared to all observed countries. A very similar situation is also observed for parameter of social mobility, where the difference in favor of sustainable competitive countries exceeds $40 \%$ and Serbia ranks the penultimate place immediately after Romania. The only parameter where Serbia shows a stronger affiliation to the group of sustainable competitive European countries is the Gini coefficient. According to this coefficient, Serbia is by far the first in the group of sustainable uncompetitive European countries, and is even better than Germany and Switzerland from the group of the most sustainably competitive European countries. As far as the group average, there is a significant difference in favor of group of sustainable competitive countries, but it is not as drastic as in the two previous parameters of social cohesion.

The aforementioned information, as well as graphical representations, unambiguously confirm the correctness of the hypothesis H1, because they show an evident gap between Serbia and the group of least competitive European countries in relation to European leaders for all indicators of social component SGCI.

The hypothesis $\mathrm{H} 2$ is also proven in the sense that the values of almost all observed indicators for Serbia are in the average range $( \pm 15 \%)$ for group of least competitive countries in Europe. Indicators that fall out of the average range of $\pm 15 \%$ are youth unemployment rate, which is in Serbia $22 \%$ weaker than the average for observed group of the least competitive countries.

\section{Comparative ReVIEW OF GCI, Sustainability-AdJuSTED GCI AND THE SOCIAL SUSTAINABILITY-ADJUSTED GCI}

With the aim of coming up with an answer to the question of whether incorporating social sustainability requirements lowers the basic competitiveness (which is represented by GCI), in this section the positions and values of following indices for Serbia and two selected groups of European countries are compared: Global Competitiveness Index, a Sustainability-adjusted GCI (GCI adjusted to overall environmental and social dimension of competitiveness) and Social sustainability-adjusted GCI (GCI suited only to the social dimension) (Table 4).

The data contained in Table 4 clearly show that the most competitive economies are also highly ranked according to requirements of total and social sustainability.

The distribution of the Social sustainability-adjusted GCI and Sustainability-adjusted $G C I$ (environmentally and socially) for group of sustainable competitive European countries is shown in Fig. 6. 
Table 4 Rank and value of observed indices (source: Bilbao-Osorio et al. (2012))

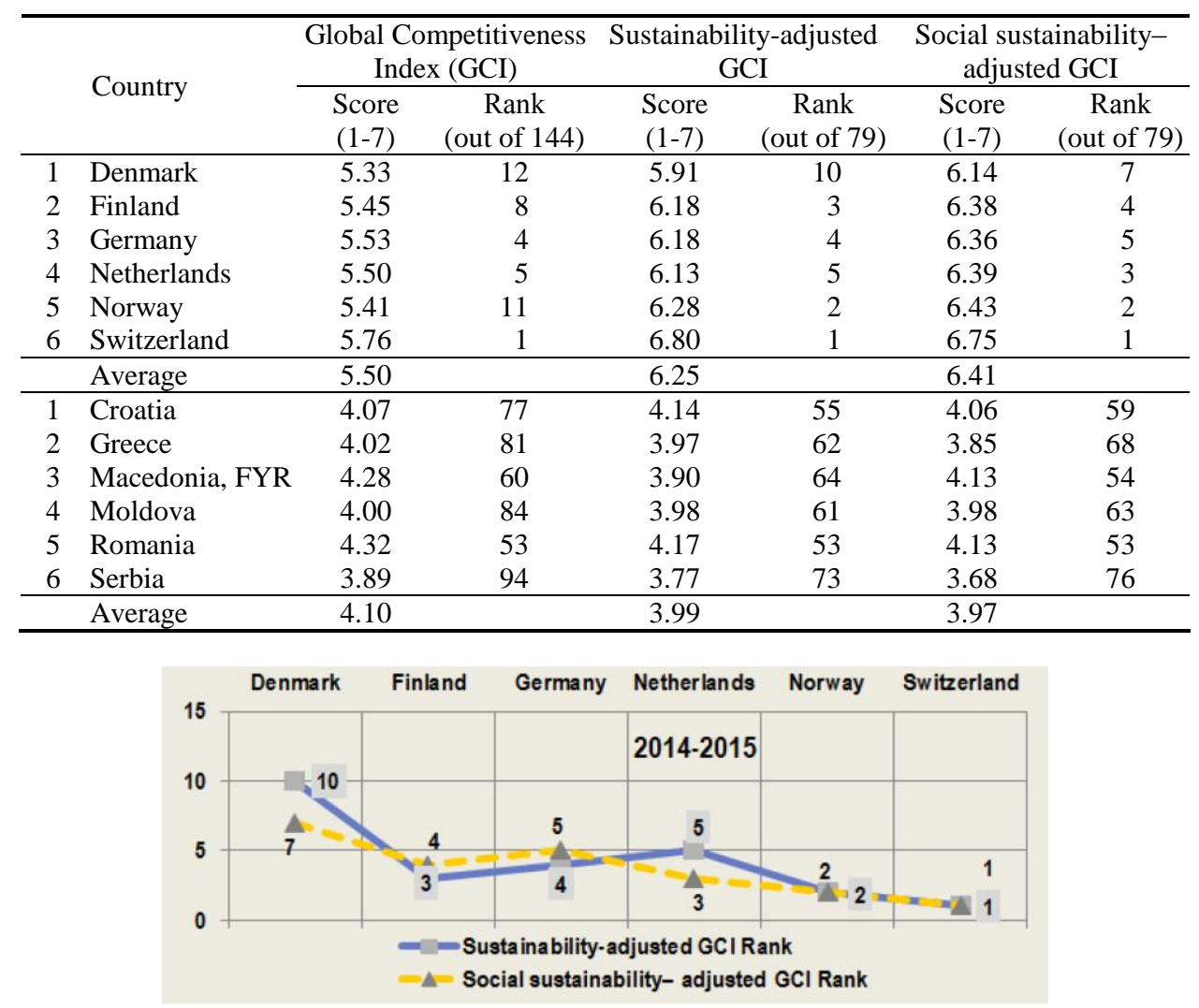

Fig. 6 The ranks of the observed indices for European socially most competitive countries

Countries such as Switzerland and Norway are leaders in ranking regarding both indicators. Switzerland is ranked as first according to the Sustainability-adjusted GCI, has good performance in all aspects of sustainable competitiveness, and shows that there is no necessary relationship between the compensation of being socially sustainable and competitive enough.

A slight misalignment of these aggregates is noticeable in some countries (Denmark and Netherlands have a significantly better social sustainability than the total, while Finland and Germany have a weaker social sustainability than the overall sustainability).

Fig. 7 illustrates the distribution of Social sustainability - adjusted GCI and Sustainabilityadjusted GCI for the least competitive European countries. In some countries in this group, the imbalance of these values is more expressive than in the group of sustainably competitive countries (Macedonia and Greece, for example), while for some almost the same position for overall and socially sustainable competitiveness is noticeable (Moldova and Romania). It is interesting that there is a shift in all countries in this group (except for the Macedonia) in favor of the social component in relation to the composite value i.e. the Sustainabilityadjusted GCI. 


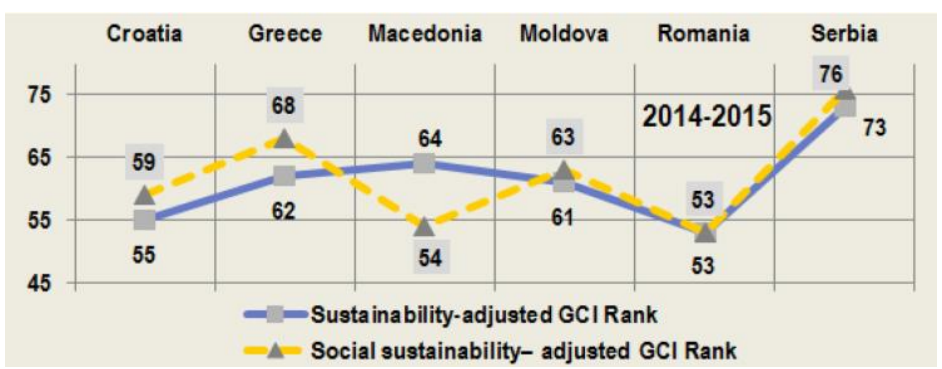

Fig. 7 The ranks of the observed indices for Serbia and European socially least competitive countries

Bearing in mind the fact that the social dimension of sustainability is becoming an increasingly important component of the competitiveness of countries, it seems useful to show its impact on the global competitiveness index.

Based on the Fig. 8, it can be generally concluded that in terms of competitiveness, including the social dimensions of sustainability, for leader countries the competitiveness that is reflected in the Social sustainability - adjusted GCI increases, while for the least competitive countries already modest competitiveness reduces further (an exception is Moldova).

It is noticeable that Serbia ranks the last according to the Social sustainabilityadjusted GCI even in its immediate environment (Fig. 8).

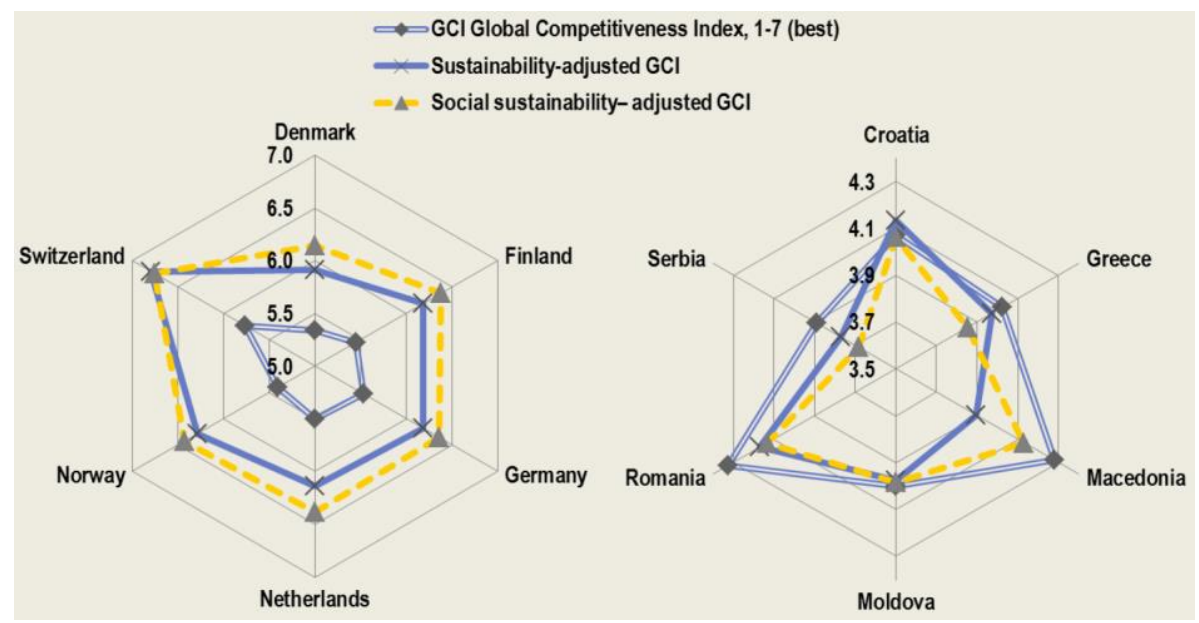

Fig. 8 The ranks of the observed indices for both groups of countries

\section{INTERDEPENDENCE OF GCI AND SOCIAL SUSTAINABILITY PILLAR}

Typically, higher levels of competitiveness lead to higher levels of economic growth, and therefore to prosperous societies, increasing the well-being of the population that can consume more accessible goods and services. However, in some cases - when the generated wealth does not reach some parts of the population, higher levels of competitiveness need 
not necessarily lead to higher levels of social sustainability. The societies in which parts of the population cannot contribute to economic activity, or where income disparities are very high, are societies that probably do not benefit from the full potential of their resources and are more prone to social instabilities.

In order to examine the character and significance of the relationship between the GCI and social sustainability pillar, the scatter diagram and the best linear fit of the aforementioned variables for the 12 surveyed countries are presented in Figure 9.

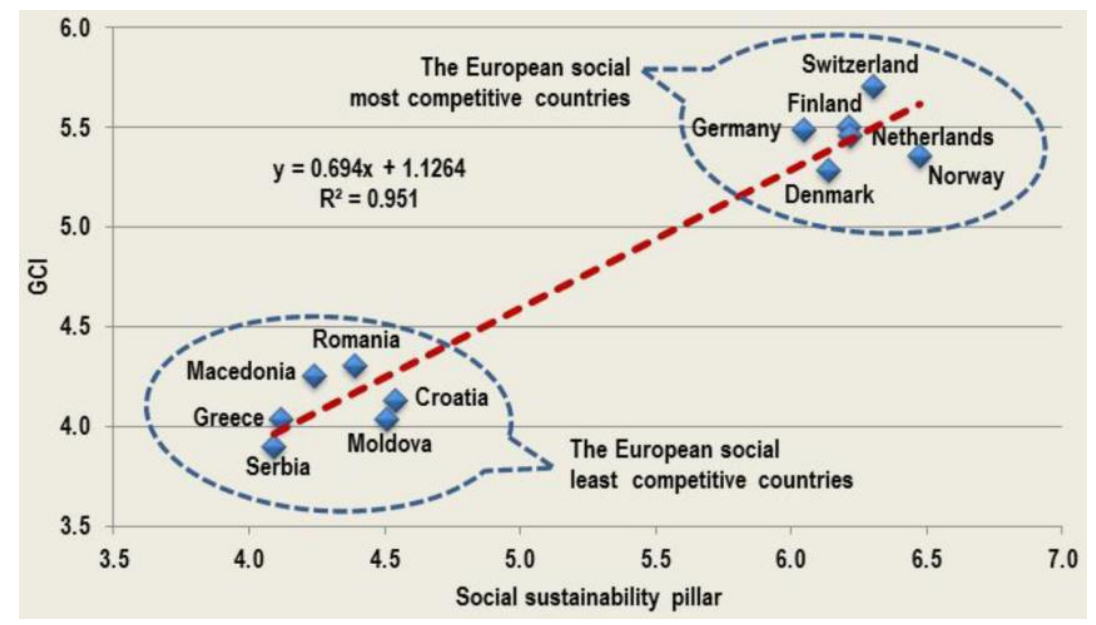

Fig. 9 Interdependence of the observed variables selected countries in 2015

Position of the selected leader and learner groups as a peripheral zone of entire population of European countries, shows an evident gap between them regarding both traditional economic competitiveness and socially sustainable competitiveness. In addition, not going into discussion about regression character of the mutual influence of the observed aggregate variables, it is evident that they have a strong correlation potential that should be explored, preferably in the context of the entire population of the European economy and in the longer time series. However, since the WEF in its GCI framework has not been monitoring the indicators of social and environmentally sustainable competitiveness until 2012-13, there is a significant constraint due to relatively small amount of available data, which narrows the usage of time lag analysis. What remains is the possibility of using additional sources for specific indicators of social sustainability pillar that are more or less available.

\section{CONCLUSION}

Research on the social dimension of the sustainable competitiveness of Serbia and selected countries has shown that the least competitive European countries as a group are significantly lagging behind the most competitive countries in most indicators in the field of social sustainability.

The most important differences are reflected in the measure of access to health care in the field of the first category of social indicators. The parameters of access to sanitation 
facilities and access to drinking water of improved quality are almost equalized with a very small shift in favor of sustainable competitive countries, while for the parameter of access to health care, the difference between groups is almost $45 \%$ in favor of group of sustainable competitive countries. This tells us that regarding the first two parameters, all the European countries have reached almost maximum availability, while for the much more sophisticated parameter relating to the availability of health care, there are still considerable differences between European countries. Serbia, regarding the first two parameters, is slightly ahead in comparison to the average values for group of the least sustainable competitive countries in Europe, while in the case of the parameter of access to health care, it has much worse score than the average of this group.

In addition, there are also significant differences in the parameter of vulnerable employment in the field of second category of indicators of social sustainability. Within the group of parameters depicting social vulnerability to economic exclusion, European leader countries are significantly and expectedly better ranked in relation to the least sustainable competitive European countries. For parameters of social safety net protection and extent of informal economy, the difference between the observed groups of countries is around $50 \%$ and $40 \%$ respectively, in favor of competitive economies. In the case of the third parameter of vulnerable employment, the difference in favor of sustainable competitive countries is more than alarming reaching a ratio of 1 to 3.2. Serbia, according the all three parameters of social vulnerability, is ranked at the lower half of the group of the least sustainably competitive European countries.

There are also great differences in values of parameter of youth unemployment in the third group of parameters of social cohesion. Social cohesion is the third group of parameters and it also shows a significant gap between the most sustainable competitive and least sustainable competitive European countries. The most noticeable difference is shown in the parameter of youth unemployment where difference in some countries exceeds a ratio of 1 to 3.5. Serbia is placed at by far the worst position compared to all countries. A very similar situation was also noticeable for the parameter of social mobility where differences in favor of leader countries exceed $40 \%$ and Serbia ranks the last. The only parameter where Serbia shows a stronger affiliation to European leaders, and not to the least competitive countries is the Gini coefficient. According to this parameter, Serbia is ranked better than all countries in this group, even very close to Germany, Switzerland and Netherland from the group of sustainable leading European countries.

Based on the analysis of the positions and values of the global competitiveness index and the Social sustainability- adjusted GCI for Serbia and selected European countries, the existence of a negative correlation between these variables is not noticed. In other words, there is no necessary relationship between the compensation of being sustainable and being competitive as defined by the World Economic Forum. On the contrary, many countries which are on the top of the rank list of competitiveness, are also the best in many aspects of social sustainability. In this context, it could be said that there is an analogy with sustainability exploration and sustainability exploitation (Maletic et al., 2014), and conclusion in the same study is that for long-term success, the simultaneous pursuit is both desirable and necessary.

The incorporation of the social dimension in the global competitiveness index deepens the lag of least competitive countries in relation to the most competitive European countries. It is noticeable that Serbia was the last even among comparable economies, and especially pertaining the social component of sustainability. 
The observed countries had noticeable differences in the values of the Sustainabilityadjusted GCI compared with Global Competitiveness Index. This fact suggests that the size of the global competitiveness index is not incompatible with the requirements of sustainability. We believe that this result can be useful in creating a practical realization of social policy and the wider policy of sustainable development, as well as the policy of improving the competitiveness of European countries in the years of the twenty-first century.

\section{REFERENCES}

Bilbao-Osorio, B., Blanke, J., Crotti, R., Hanouz, M. D., Fidanza, B., Geiger, T., Ko, C., \& Serin, C. (2012). Assessing the Sustainable Competitiveness of Nations. The Global Competitiveness Report 2012 - 2013.

Blanke, J. (2013). Assessing the Sustainable Competitiveness of Nations. The Global Competitiveness Report 2012-2013, (pp. 49-68).

Coenen, L., \& Diaz Lopez, F. J. (2010). Comparing systems approaches to innovation and technological change for sustainable and competitive economies: an explorative study into conceptual commonalities, differences and complementarities. Journal of Cleaner Production, 18, 1149-1160.

Cvetanovic, S., Despotovic, D., Zivkovic, L., \& Nedic, V. (2014). Environmental Dimension of Sustainable Competitiveness of Serbia and Selected European Countries. Bulgarian Journal of Agricultural Science, 20(4), 767-778.

Despotovic, D., Cvetanovic, S., Nedic, V., \& Despotovic, M. (2015). Economic, social and environmental dimension of sustainable competitiveness of European countries. Journal of Environmental Planning and Management, 1-23.

Dragicevic, M. (2012). Competitiveness - project for Croatia (in Serbian). Zagreb: Skolska knjiga.

Filipovic, M., \& Despotovic, D. (2014). Analysis of Sustainable Competitiveness of European Countries in 2013. Ekonomika, 60(4), 77-91.

Global Competitiveness Report 2015-2016. (n.d.). Retrieved August 01, 2016, from http://reports.weforum.org/ global-competitiveness-report-2015-2016/

Hatzichronoglou, T. (1996). Globalisation and Competitiveness: Relevant Indicators. OECD Science, Technology and Industry Working Papers, 1996/05, OECD Publishing,.

Krugman, P. (1994). Competitiveness: a dangerous obsession. Foreign Affairs, 73, 28-28.

Maletic, M., Maletic, D., Dahlgaard, J. J., Dahlgaard-Park, S. M., \& Gomiscek, B. (2014). Sustainability exploration and sustainability exploitation: From a literature review towards a conceptual framework. Journal of Cleaner Production, 79, 182-194.

Mirkov, A. (2012). Social sustainability of the city: the analysis of the concept. Sociologija, (pp. 55-70).

Perez-Moreno, S., Rodriguez, B., \& Luque, M. (2015). Assessing global competitiveness under multi-criteria perspective. Economic Modelling,

Schwab, K., \& Sala-i Martin, X. (2011). The global competitiveness report 2011-2012. Geneva, Switzerland: World Economic Forum.

Stoneman, P. (1995). Handbook of the economics of innovation and technological change. Blackwell handbooks in economics. 


\section{SOCIJALNA DIMENZIJA ODRŽIVE KONKURENTNOSTI SRBIJE I SELEKTOVANIH ZEMALJA EVROPE}

Centralna ideja održive konkurentnosti predstavlja traganje za modelom razvoja koji bi uravnotežio ekonomski prosperitet, socijalnu održivost $i$ upravljanje životnom sredinom. Rad je posvećen analizi socijalnog aspekta održive konkurentnosti sa ciljem da se sagleda relativna pozicija Republike Srbije u odnosu na selekovane najkonkurentnije i najmanje konkurentne zemlje Evrope u 2014. godini. Pošlo se od potrebe da se na neophodnost unapređenja održive konkurentnosti zemalja ne sme prilaziti na način koji ekonomsku, socijalnu i ekološku dimenziju konkurentnosti tretira kao oblasti u konfliktu. Na osnovu podataka Svetskog ekonomskog foruma prezentovana je kvantitativna, kvalitativna i grafička analiza socijalne dimenzije održive konkurentnosti Srbije u odnosu na šest najkonkurentnijih $i$ šest najmanje konkurentnih zemlja Evrope u 2014. godini na osnovu vrednosti Indeksa socijalno održive konkurentnosti (Social sustainability-adjusted GCI). Korišćenjem proste korelacione analize istražena je međuzavisnost globalnog indeksa konkurentnosti i stuba socijalne odrzivosti (Social sustainability pillar) na primeru selektovanih zemalja Evrope u 2014. godini.

Ključne reči: održivi razvoj, održiva konkurentnost, socijalna dimenzija održive konkurentnosti. 